\title{
Femininity and the Librarian-
}

\section{Another Test}

This study examined the sex-role orientation of library science students at a large university in the western United States. Each student enrolled in the M.L.S. program filled out the Bem Sex-Role Inventory. This gave each student a masculinity, a femininity, and an androgyny score. These scores were compared with a normative group provided by the author of the inventory. No significant differences were found between the two groups. It was concluded that the library science students were no different in their sex-role orientation from the normative population. This finding is opposite to those found by other studies dated both by instruments used and current societal trends.

$\mathbf{T}$ HOSE WHO WRITE on the subject of the librarian's image agree that there need to be improvements made in that image. The librarian is seen as a "kindly maiden lady in Red Cross shoes behind the circulation desk." 1 In fact, librarianship as a whole is viewed as a female profession that is weak, conservative, nonintellectual, and, most probably, boring.

In the midst of this situation is the male who happens to be a librarian. Since the turn of the twentieth century this creature, at best, has been considered "subnormal" as far as "normal" men go. This image of the male has some scientific basis; by use of personality tests it has been "proved" that males in librarianship are more feminine than the "normal" male.

\section{EARLIER TESTS}

Alice I. Bryan's study of male and female librarians showed that all exhibited traits of orderliness, responsibility, conscientiousness, conservatism, and conformism. They also lacked vigor, imagination, and ambition. They were shown to be introspective rather than outgoing, insecure, and more strongly interested in cultural and intellec-

Robert L. Turner, Jr., is the reference services librarian, Learning Resources Center, University of Texas of the Permian Basin, Odessa. tual rather than in political and economic ideas; and they rated high in femininity. ${ }^{2}$ Thus, thanks to scientific methods, the librarian's image and sex-role identitywhether true or not-were set.

In the 1960s two other researchers studied the personality of the librarian. Stuart Baillie, who studied the relationship between the library school and job success, gave his subjects the California Psychological Index (CPI) to fill out. The CPI is a paper-and-pencil test yielding eighteen personality scores, one of which is a measure of femininity. With this instrument Baillie found, among other things, that librarians were significantly (at the .001 level) more feminine than the normative sample provided by the authors of the CPI manual. ${ }^{3}$

Another person who investigated this idea was Howard Clayton. He was trying to determine whether there were distinctive personality characteristics that could be identified, through statistical measurement, among male students of library science who were enrolled at a major midwestern university during the summer of 1967 . He developed a composite profile that was derived by computing the mean of fourteen adult occupational groups (the normative group) listed in the CPI manual. He compared his subjects with this composite profile and found that his subjects were 
lower on sixteen of the eighteen personality scales. On one, self-acceptance, the two groups were equal, and on one, the femininity scale, his subjects were significantly higher than the norm, which indicated that they were more feminine than the "normal" male. $^{4}$

It now should be asked: Are the results presented really relevant to the masculinity-femininity roles as they are reflected in our society today? According to Newmyer the answer would have to be a resounding no. As pointed out in her article, the problem is not so much whether male librarians are more feminine than the norm, but rather whether the tests that so indicate are really valid, and whether the tests are measuring what is supposed to be measured. The answer is no. ${ }^{5}$

If the history of the masculinityfemininity scales that have been used on librarians to determine that they are feminine in sex-role orientation is traced, some interesting insights will be found. In the two major personality inventories (the MMPI-Minnesota Multiphasic Personality Inventory-and the CPI), though the terminology differs slightly, the questions used are measuring the same personality traitssuch as aggressiveness versus nurturance and ambition versus abasement-as indexes of masculinity and femininity.

Since the M-F scales are similar in these instruments, the femininity scale of the CPI will be examined to demonstrate the type of questions asked and their "correct" responses for females. Males, in order to be considered masculine, should answer in the opposite manner.

I want to be an important person in the community. (False)

I'm not the type to be a political leader. (True)

I like mechanics magazines. (False)

I think I would like the work of a librarian. (True)

I'm pretty sure I know how we can settle the international problems we face today. (False)

I must admit I feel sort of scared when I move to a strange place. (True)

I like to go to parties and other affairs where there is lots of loud fun. (False)

If I were a reporter, I would like very much to report news of the theater. (True)

I would like to be a nurse. (True)

It is hard for me to "bawl out" someone who is not doing his job properly. (True)

I very much like hunting. (False)

I would like to be a soldier. (False)

I think I could do better than most of the present politicians if I were in office. (False)

I like to be with a crowd who play jokes on one another. (False)

In school I was sometimes sent to the principal for cutting up. (False)

I think I would like the work of a building contractor. (False)

When I work at something, I like to read and study about it. (False)

I am somewhat afraid of the dark. (True)

I like to boast about my achievements every now and then. (False)

I think I would like to drive a racing car. (False)

I must admit that I enjoy playing practical jokes on people. (False)

At times I feel like picking a fistfight with someone. (False)

The thought of being in an automobile accident is very frightening to me. (True)

I think I would like the work of a garage mechanic. (False)

A windstorm terrifies me. (True)

I think I would like the work of a dress designer. (True)

I think I would like the work of a clerk in a large department store. (True) ${ }^{6}$

Notice that the fourth item (liking the work of a librarian) is keyed true only for females. If males answer the question "true," by definition they are feminine. This choice has been labeled feminine because at the time of the question construction the fact that more women than men were librarians was a statistical reality. However, this does not reflect the true psychological nature of the profession or sex role as it is defined today.

The author of the test summarizes the model personalities of the two sexes who score high on the femininity scale (i.e., they answer the questions the way females "should") in the following manner: For males, the terms he uses to describe them are appreciative, complaining, feminine, formal, meek, nervous, self-denying, sensitive, weak, worrying. Females answering in the exact same way are described as conscientious, discreet, generous, [having a] gentle helping nature, self-controlled, sympathetic, tactful, warm.

Those individuals who scored low on 
femininity (i.e., answered the way males "should") are described as follows: For males, the description runs adventurous, aggressive, clear thinking, daring, impulsive, masculine, outgoing, pleasure-seeking, show-off, strong.

For females the description is coarse, dissatisfied, lazy, masculine, pleasure-seeking, restless, robust, self-centered, touchy, tough. ${ }^{7}$

It is fairly easy to see on this scale, which is one continuum-males on one end and females at the other-that if two people answer identically, one male the other female, one of them is described in positive terms and as being socially acceptable, while the other is described in negative terms and as being socially unacceptable. The same sort of slant occurs in the other personality scales of the CPI.

Thus, if this image of the male librarian is to be actually tested, a sex-role inventory without the problems of the traditional scales, such as the CPI, would be needed to test the hypothesis that male librarians are significantly more feminine than the "normal" male.

\section{THE BEM \\ SEX-ROLE INVENTORY}

As can be seen from the above information, many tests that are being used to measure masculinity-femininity are not measuring the traits as they are represented in today's society. Realizing this fact, Sandra Bem, in 1973, developed a scale that corrected for the misconceptions of the other M-F scales that have tended to obscure two very important ideas. The first is that many individuals might be "androgynous"- that is, both masculine and feminine, both assertive and yielding, etc.- depending upon the situational appropriateness of these various forms of behavior. The second idea is that strongly sex-typed individuals might be seriously limited in the range of behavior available to them as they move from situation to situation. ${ }^{8}$

The Bem Sex-Role Inventory (BSRI) has a number of features that distinguish it from other M-F scales.

First, it includes separate masculinity and femininity scales, each of which contains twenty items (see table 1).

Second, because BSRI was founded on the idea that the sex-typed person was someone who had internalized society's sex-typed standards of desirable behavior for men and women, these personality characteristics were selected as masculine or feminine on the basis of sex-typed social desirability and not on the basis of differential endorsement by males and females as most other inventories have done. That is, a

TABLE 1

Items ON THE MASCULINITY, FEMININITY, AND Social Desirability SCALES OF THE BSRI

\begin{tabular}{|c|c|c|}
\hline Masculine Items & Feminine Items & Neutral Items \\
\hline 49. Acts as a leader & 11. Affectionate & 51. Adaptable \\
\hline 46. Aggressive & 5. Cheerful & 36. Conceited \\
\hline 58. Ambitious & 50. Childlike & 9. Conscientious \\
\hline 22. Analytical & 32. Compassionate & 60. Conventional \\
\hline 13. Assertive & 53. Does not use harsh language & 45. Friendly \\
\hline 10. Athletic & 35. Eager to soothe hurt feelings & 15. Happy \\
\hline 55. Competitive & 20. Feminine & 3. Helpful \\
\hline 4. Defends own beliefs & 14. Flatterable & 48. Inefficient \\
\hline 37. Dominant & 59. Gentle & 24. Jealous \\
\hline 19. Forceful & 47. Gullible & 39. Likable \\
\hline 25. Has leadership abilities & 56. Loves children & 6. Moody \\
\hline 7. Independent & 17. Loyal & 21. Reliable \\
\hline 52. Individualistic & 26. Sensitive to the needs of others & 30. Secretive \\
\hline 31. Makes decisions easily & 8. Shy & 33. Sincere \\
\hline 40. Masculine & 38. Soft-spoken & 42. Solemn \\
\hline 1. Self-reliant & 23. Sympathetic & 57. Tactful \\
\hline 34. Self-sufficient & 44. Tender & 12. Theatrical \\
\hline 16. Strong personality & 29. Understanding & 27. Truthful \\
\hline 43. Willing to take a stand & 41. Warm & 18. Unpredictable \\
\hline 28. Willing to take risks & 2. Yielding & 54. Unsystematic \\
\hline
\end{tabular}

\footnotetext{
Note: The number preceding each item reflects the position of each adjective as it actually appears on the inventory.
} 
characteristic qualified as masculine if it was judged to be more desirable in American society for a man than for a woman, and it qualified as feminine if the reverse was true.

Third, the BSRI characterizes a person as masculine, feminine, or androgynous as a function of the difference between his or her endorsement of masculine and feminine personality characteristics.

There is also a third twenty-item scale on the BSRI, the social desirability scale, that is completely neutral in regard to sex. It was used in the development of the scale to ensure that the inventory would not simply be tapping a general tendency to endorse socially desirable traits. Now it provides a neutral context for the masculinity and femininity scales.

\section{The Present Study}

It was the purpose of this study to test the sex-role orientation of library science students to see if it was different from that of the "normal" population. Two hypotheses were tested:

1. There is no statistically significant (at the .05 level) difference in the sex-role orientation of the male library science students as compared with the normative sample on the Bem Sex-Role Inventory.

2. There is no statistically significant (at the .05 level) difference in the sex-role orientation of the female library science student as compared with the normative sample on the Bem Sex-Role Inventory.

\section{Method}

To test these two hypotheses the following procedure was used: Library science students enrolled in the spring 1977 term at a major university in the western United States were asked to fill out the sixty-item BSRI.

The inventory gave the students sixty personality characteristics and asked them to rate themselves on each characteristic on a seven-point scale ranging from 1, "Never or almost never true," to 7, "Always or almost always true."

On the basis of the responses each person received three major scores: a masculinity score, a femininity score, and an androgyny score. The androgyny score was defined as the femininity score minus the masculinity score as outlined in both the Bem and the Strahan papers. ${ }^{9}$

The masculinity and femininity scores indicate the extent to which a person endorses masculine and feminine personality characteristics as self-descriptive. Masculinity equals the mean self-rating for all endorsed masculine items, and femininity equals the mean self-rating for all endorsed feminine items. Both can range from 1 to 7 .

The androgyny score reflects the relative amount of masculinity and femininity that the person includes in his or her selfdescription, and, as such, it best characterizes the nature of the person's total sex role. It should be noted that in this conception the masculine sex role represents not only the endorsement of the masculine attributes but also the simultaneous rejection of feminine attributes. Similarly, a feminine sex role represents not only the endorsement of the feminine sex role but also the rejection of the masculine sex role.

The closer the androgyny score is to zero the more the person is androgynous. The androgynous sex role represents the equal endorsement of both masculine and feminine attributes. Thus, the androgynous individual should be able to remain sensitive to the changing constraints of the situation and engage in whatever form of behavior seems most effective at the moment regardless of its stereotype as appropriate for one sex or the other. ${ }^{10}$ Thus, the individual can engage freely in both masculine and feminine forms of behavior as appropriate to the given situation.

After the scores for the library science group were computed, those scores were compared with the normative data supplied by Bem. A t-test was used to compare the two groups to determine if the group of library science students was significantly different from the normative sample that consisted of 917 college students from two different colleges in the spring of 1973. On the basis of this comparison the two hypotheses were examined to see if the library science students were statistically different in their sex-role orientations from the normative group. 


\section{Analysis of Data}

All students in the M.L.S. program at a large university in the western United States who were enrolled and taking classes during the spring term of 1977 filled out the Bem Sex-Role Inventory. This group consisted of sixteen males and twenty-six females.

Three scores were obtained from this inventory. One was the score on the masculinity scale, which consisted of twenty questions. Another was the score obtained on the femininity scale, which also consisted of twenty questions. A third score was derived from the two just mentioned. This was called the androgyny score and was computed by subtracting the score obtained on the masculinity scale from the score obtained on the femininity scale.

A negative score indicates that the individual is identifying more with the masculine role, while the positive score means that the individual is identifying more with the female role. The nearer the score is to zero, the more androgynous is the individual; that is, he or she is equally adept at taking the male or female role in the appropriate circumstances. The scores for each male subject are presented in table 2 . The scores for each female subject are presented in table 3 . The scores on the masculinity and femininity scales can range from 1 to 7 .

This library science group (LIS) was compared with the normative group supplied by

TABLE 2

SCORES OF LIBRARY SCIENCE MALES ON THE BSRI

\begin{tabular}{cllc}
\hline Subject & $\begin{array}{c}\text { Masculinity } \\
\text { Score }\end{array}$ & $\begin{array}{c}\text { Femininity } \\
\text { Score }\end{array}$ & $\begin{array}{c}\text { Adnrogyny } \\
\text { Score }\end{array}$ \\
\hline 1 & 4.85 & 3.85 & -1.0 \\
2 & 5.5 & 4.9 & -0.6 \\
3 & 4.4 & 4.3 & -0.1 \\
4 & 6.25 & 5.05 & -1.2 \\
5 & 5.0 & 4.35 & -0.65 \\
6 & 5.8 & 5.45 & -0.35 \\
7 & 4.35 & 4.5 & 0.15 \\
8 & 6.8 & 3.85 & -2.95 \\
9 & 4.9 & 4.3 & -0.6 \\
10 & 4.7 & 4.7 & 0.0 \\
11 & 4.75 & 4.75 & 0.0 \\
12 & 4.9 & 4.5 & -0.4 \\
13 & 5.9 & 5.65 & -0.25 \\
14 & 5.85 & 4.75 & -1.1 \\
15 & 4.95 & 5.75 & 0.8 \\
16 & 4.8 & 5.25 & 0.45 \\
\hline
\end{tabular}

TABLE 3

SCORES OF LIBRARY SCIENCE FEMALES ON THE BSRI

\begin{tabular}{cllc}
\hline \hline Subject & $\begin{array}{c}\text { Masculinity } \\
\text { Score }\end{array}$ & $\begin{array}{c}\text { Femininity } \\
\text { Score }\end{array}$ & $\begin{array}{c}\text { Androgyny } \\
\text { Score }\end{array}$ \\
\hline 1 & 4.75 & 4.7 & -0.05 \\
2 & 4.8 & 5.9 & 1.1 \\
3 & 4.65 & 5.5 & 0.85 \\
4 & 4.65 & 5.85 & 1.2 \\
5 & 5.4 & 4.6 & -0.8 \\
6 & 4.1 & 4.7 & 0.6 \\
7 & 5.2 & 5.85 & 0.65 \\
8 & 4.2 & 6.05 & 1.85 \\
9 & 4.3 & 6.65 & 1.35 \\
10 & 3.7 & 5.6 & 1.9 \\
11 & 5.35 & 4.6 & -0.75 \\
12 & 4.5 & 5.3 & 0.8 \\
13 & 4.0 & 4.2 & 1.2 \\
14 & 4.9 & 6.05 & 1.15 \\
15 & 4.55 & 5.75 & 1.2 \\
16 & 5.65 & 3.85 & -1.8 \\
17 & 4.6 & 6.2 & 1.6 \\
18 & 4.5 & 5.35 & 0.85 \\
19 & 5.4 & 5.85 & 0.45 \\
20 & 4.7 & 4.0 & -0.7 \\
21 & 3.5 & 5.15 & 1.65 \\
22 & 4.2 & 5.55 & 1.35 \\
23 & 4.45 & 4.8 & 0.35 \\
24 & 4.4 & 4.8 & 0.4 \\
25 & 4.45 & 5.85 & 1.4 \\
26 & 4.8 & 4.45 & -0.35 \\
\hline & & & \\
& & & \\
\hline
\end{tabular}

Bem for the BSRI. This normative group consisted of 561 males and 356 females who were tested in two universities in California. Tables 4 and 5 show the results of that comparison. Table 6 compares the LIS males with the LIS females.

As can be seen from table 4 there are no significant differences on the masculinity, femininity, and androgyny scores between the male library science students and the normative male group. It appears that these male library science students are no more feminine or masculine in their sex-role orientation than the males in the normative group. These findings contradict those cited previously that indicate male library science students were significantly more feminine than the average male.

As can be seen from table 5, the female library science students and the normative group did not significantly differ in their mean scores on the masculinity scale. On the femininity scale of the inventory the LIS females scored significantly (at the .05 level) higher than did the normative group. However, on the androgyny scale there were no significant differences. 
TABLE 4

A Comparison of LIS Males With the

Normative MaLES ON THE BSRI

\begin{tabular}{lrrr}
\hline \hline & $\begin{array}{c}\text { LIS Males } \\
(\mathrm{N}=16)\end{array}$ & $\begin{array}{c}\text { Normative Males } \\
(\mathrm{N}=561)\end{array}$ & $\begin{array}{c}\text { T-score } \\
(\mathrm{df}=575)\end{array}$ \\
\hline Masculinity & $\overline{\mathrm{X}}=5.23$ & $\mathrm{X}=4.97$ & 1.53 \\
Score & $\mathrm{SD}=0.68$ & $\mathrm{SD}=0.67$ & 1.82 \\
Femininity & $\overline{\mathrm{X}}=4.74$ & $\overline{\mathrm{X}}=4.48$ & \\
Score & $\mathrm{SD}=0.56$ & $\mathrm{SD}=0.57$ & 0 \\
Androgyny & $\overline{\mathrm{X}}=-0.49$ & $\overline{\mathrm{X}}=-0.49$ & \\
Score & $\mathrm{SD}=0.83$ & $\mathrm{SD}=0.85$ & \\
\hline
\end{tabular}

TABLE 5

A Comparison of LIS Females WITH THE Normative Females ON THE BSRI

\begin{tabular}{|c|c|c|c|}
\hline & $\begin{array}{l}\text { LIS Females } \\
(\mathrm{N}=26)\end{array}$ & $\begin{array}{l}\text { Normative Females } \\
\qquad(\mathbf{N}=356)\end{array}$ & $\begin{array}{c}\begin{array}{c}\text { T-score } \\
(\mathrm{df}=380)\end{array}\end{array}$ \\
\hline $\begin{array}{l}\text { Masculinity } \\
\text { Score }\end{array}$ & $\begin{array}{r}\bar{X}=4.60 \\
S D=0.51\end{array}$ & $\begin{aligned} \bar{X} & =4.57 \\
\mathrm{SD} & =0.70\end{aligned}$ & 0.25 \\
\hline $\begin{array}{l}\text { Femininity } \\
\text { Score }\end{array}$ & $\begin{aligned} \bar{X} & =5.28 \\
\mathrm{SD} & =0.64\end{aligned}$ & $\begin{aligned} \bar{X} & =5.03 \\
S D & =0.53\end{aligned}$ & $2.05^{*}$ \\
\hline $\begin{array}{l}\text { Androgyny } \\
\text { Score }\end{array}$ & $\begin{aligned} \bar{X} & =0.67 \\
S D & =0.91\end{aligned}$ & $\begin{aligned} \bar{X} & =0.45 \\
\mathrm{SD} & =0.94\end{aligned}$ & 1.16 \\
\hline
\end{tabular}

$\cdot P>05$.

TABLE 6

a Comparison of LIS Males with LIS Females on the BSRI

\begin{tabular}{lrrr}
\hline \hline & \multicolumn{1}{c}{$\begin{array}{c}\text { Males } \\
(\mathrm{N}=16)\end{array}$} & \multicolumn{1}{c}{$\begin{array}{c}\text { Females } \\
(\mathrm{N}=26)\end{array}$} & $\begin{array}{c}\text { T-score } \\
(\mathrm{df}=40)\end{array}$ \\
\hline $\begin{array}{l}\text { Masculinity } \\
\text { Score }\end{array}$ & $\overline{\mathrm{X}}=5.23$ & $\overline{\mathrm{X}}=4.60$ & $3.12^{*}$ \\
Femininity & $\mathrm{SD}=0.68$ & $\mathrm{SD}=0.51$ & $2.95^{*}$ \\
Score & $\overline{\mathrm{X}}=4.74$ & $\overline{\mathrm{X}}=\mathbf{5 . 2 8}$ & $4.16^{*}$ \\
Androgyny & $\mathrm{SD}=0.56$ & $\mathrm{SD}=0.64$ & \\
Score & $\overline{\mathrm{X}}=-0.49$ & $\overline{\mathrm{X}}=0.67$ & \\
\hline
\end{tabular}

$\cdot \mathrm{P}>01$.

Looking at the total results, it appears that the library science females answered in a more feminine way the items on the femininity scale. However, when it comes to the ability to function well in either sex role, as an androgynous individual should, they are no different in that ability from the normative group. It must be concluded, then, that the library science females are not significantly different in their sex-role orientation from the members of the normative group.

When the library science males and females were compared with each other, it was found that the males and females were significantly different (at the .01 level) on all three of the scales, as is shown in table 6 .

\section{ConClusions}

What can be concluded from this study on library science students and their sexrole orientation in general? Nothing can, or should, be inferred for any larger population than the one studied. In order for this study to be generalizable to a larger population of library science students, a random sample of library science students would have had to be taken and sampled, and then conclusions could have been made about the larger population. However, this was not done.

The major importance of this study is that it casts some doubt on the other studies that have tried to deal with the concept of sex role of the librarian or library science stu- 
dent, in that it questions the validity of the instruments used in these other studies in measuring sex role, especially the CPI, and it demonstrates that significantly different results are obtained using a newer instrument that has, to a great extent, been freed of the more limiting concepts used to form other sex-role inventories.

It could be asked if this finding is part of a societal trend toward a less strict definition of sex roles. I believe not. As shown by the Bem inventory, there are still definite sex roles for each sex. The students studied showed many differences between the male and female endorsement of sex roles. The question becomes: Are males and females in library science different from other males and females in the society in their sex-role orientation, as has been suggested by the previously mentioned studies? It appears that they are not.

It is suggested that many more studies should be done using this instrument and others that may be developed in the ongoing search for knowledge about the personality and characteristics of the library science student and the librarian.

\section{REFERENCES}

1. Jesse H. Shera, The Compleat Librarian and Other Essays (Cleveland: Case Western Reserve Press, 1971), p.69-70.

2. Alice I. Bryan, The Public Librarian (New York: Columbia Univ. Pr., 1952).

3. Stuart Baillie, Library School and Job Success (Denver: University of Denver, Graduate School of Librarianship, 1964).

4. Howard Clayton, "Femininity and Job Satisfaction among Male Library Students at One Midwestern University," College \& Research Libraries 31:388-98 (Nov. 1970).

5. Jody Newmyer, "The Image Problem of the Librarian: Femininity and Social Control," Journal of Library History 11:44-67 (Jan. 1976).

6. Harrison Gough, "Identifying Psychological Femininity," Educational \& Psychological
Measurement 12:429-30 (Aug. 1952).

7. Harrison Gough, "An Interpreter's Syllabus for the California Psychological Inventory," in P. McReynolds, ed., Advances in Psychological Assessment, 1 (Palo Alto: Science and Behavior Books, 1971), p.73.

8. Sandra L. Bem, "The Measurement of Psychological Androgyny," Journal of Consulting \& Clinical Psychology 42:155-62 (April 1974).

9. Ibid.; Robert F. Strahan, "Remarks on Bem's Measurement of Psychological Androgyny: Alternative Methods and a Supplementary Analysis," Journal of Consulting \& Clinical Psychology 43:568-71 (Oct. 1975).

10. Sandra L. Bem, "Sex Role Adaptability: One Consequence of Psychological Androgyny," Journal of Personality and Social Psychology 31:634-43 (April 1975). 


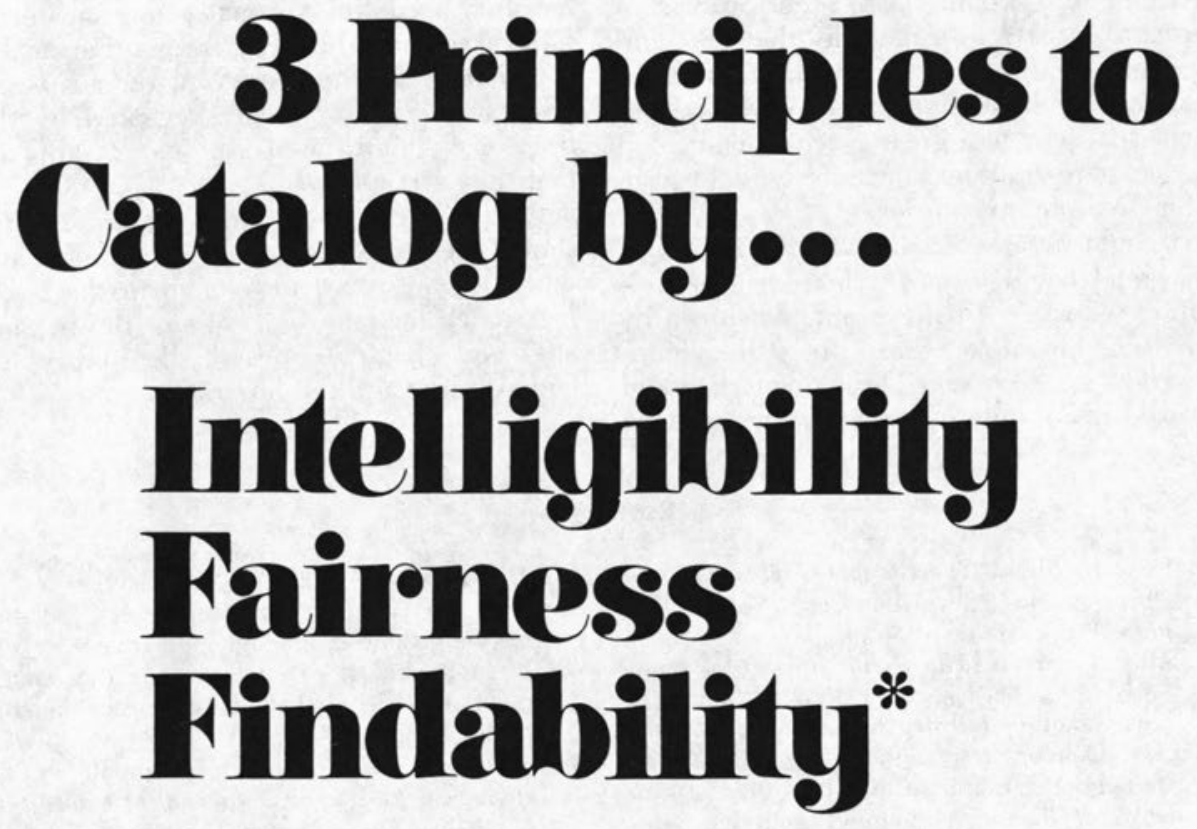

The Joy of Cataloging: Essays, Letters and Other Explosions is not a manual or a textbook on cataloging. Representing the author's major writing and thought in the field of "alternative" and public library cataloging since 1971, this book shows cataloging to be fun, challenging and useful. By Sanford Berman. Available June 1980, ISBN 0-912700-51-3. $\$ 15.00(\mathrm{t})$.

Closing the Catalog is the proceedings from LITA's institutes on the catalog. Planning for the closing, the impact on reference services, and case histories of libraries already having closed their catalogs are some of the topics covered. Edited by Kaye Gapen and Bonnie Juergens. Available June 1980, ISBN 0-912700-56-4. \$16.50.

Cataloging and Classification of Non-Western Material: Concerns, Issues, and Practices presents the controversial issues involved in working with a non-Roman alphabet. Cataloging and classification tools are discussed and recommendations for changes are made. Edited by Mohammed M. Aman. A Neal-Schuman Professional Book. Available June 1980, ISBN 0-912700-06-8. $\$ 18.50(\mathrm{t})$.

\section{Order your copies today!}

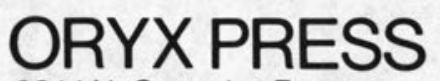

2214 N. Central at Encanto

Phoenix, AZ 85004 • (602) 254-6156 